\title{
ANALISIS KELAYAKAN USAHA PENGOPRASIAN ALAT PENANGKAP IKAN (API) BAGAN PERAHU DI TEMPAT PELELANGAN IKAN DESA LAMURUKUNG KECAMATAN LAMURU KABUPATEN BONE
}

\section{ANALYSIS OF BUSINESS FEASIBILITY IN OPERATION OF LIFT NET OF LAMURUKUNG VILLAGE, LAMURU SUB-DISTRICT, BONE DISTRICT}

\author{
Muhammad Maskur ${ }^{1}$, Arham Rumpa1, Supryady', Mohammad Roin Najih², Hawati' \\ 1 Dosen Politeknik Kelautan dan Perikanan Bone, Sulawesi Selatan, Indonesia \\ 2 Staf Pengajar Sekolah Usaha Perikanan Menengah (SUPM) Bone, Sulawesi Selatan, Indonesia \\ "Korespondensi: Muhammad_masykur@ymail.com (M Maskur) \\ Diterima 29 Juli 2019 - Disetujui 24 September 2019
}

\begin{abstract}
ABSTRAK. Bagan perahu merupakan alat tangkap yang prinsip kerjanya memanfaatkan cahaya lampu untuk mengumpulkan gerombolan ikan baik yang bersifat fototaksis positif atau ikan yang ingin mencari makan di sekitar cahaya lampu dan pada umumnya lebih efektif digunakan untuk menangkap ikan-ikan pelagis seperti ikan Teri, ikan Tongkol, dan cumi. Tempat Pelelangan Ikan (TPI) Desa Lamurukung merupakan salah satu pusat aktivitas perikanan tangkap di Desa Lamurukung Kecamatan Lamuru Kabupaten Bone, dimana jenis alat tangkap di TPI Desa Lamurukung mayoritas menggunakan alat penangkap ikan bagan perahu. Penelitian ini bertujuan untuk menganalisi kelayakan usaha pada pengoprasian alat penangkap ikan bagan perahu dengan beberapa indikator yaitu Analisa Rugi/Laba, Payback Period (PP), Analisa Net Present Value (NPV), dan Analisa Revenue Cost Ratio (R/C Ratio). Hasil penelitian menunjukan bahwa nilai keuntungan per tahun sebesar Rp. 233.464.667, PP sebesar 1,56, NPV sebesar 53.722.736,4, dan R/C Ratio sebesar 1,95, sehingga usaha pengoprasian alat penangkapan ikan bagan perahu layak untuk dilanjutkan dan dikembangkan.
\end{abstract}

KATA KUNCI: Kelayakan usaha, API, bagan perahu

ABSTRACT. Lift net is a fishing gear whose working principle is to use light to collect of fish that are either positive phototaxis or fish that want to find food around the lights and are generally more effectively used to catch pelagic fish such as anchovy, tongkol, and squid. The Fish Auction Facility of Lamurukung Village is one of the centers of fishing activities in Lamurukung Village, Lamuru Subdistrict, Bone Regency, where the majority of fishing gear in fish auction facility Lamurukung Village use lift net. This study aims to analyze the business feasibility of operating a fishing gear charters with several indicators namely Loss / Profit Analysis, Payback Period (PP), Net Present Value Analysis (NPV), and Revenue Cost Ratio Analysis (R / C Ratio). research shows that the annual profit value of Rp. 233,464,667, PP of 1.56, NPV of 53,722,736.4, and R/C Ratio of 1.95, so that the operation of lift net is feasible to be continued and developed.

\section{KEYWORDS: Business feasibility, API, and left net}

\section{Pendahuluan}

Alat tangkap yang digunakan di Desa Lamurukung dalam usaha penangkapan ikan salah satunya adalah Alat Penangkap Ikan (API) bagan cungkil, dimana bagan cungkil merupakan alat tangkap yang prinsip kerjanya memanfaatkan cahaya lampu untuk mengumpulkan gerombolan ikan baik yang bersifat fototaksis positif atau ikan yang ingin mencari makan di sekitar cahaya lampu dan pada umumnya lebih efektif digunakan untuk menangkap ikan pelagis kecil seperti ikan teri, ikan 
layang, ikan tongkol dan cumi. Alat bantu lampu umumnya digunakan saat operasi penangkapan bagan, dengan tujuaan ikan yang menjadi target penangkapan memiliki sifat tertarik terhadap cahaya (fototaksis positif) (Suherman dan Fitri, 2005). Sumberdaya ikan pelagis kecil memiliki peranan dalam pengembangan ekonomi wilayah, khususnya wilayah yang memiliki potensi sumberdaya ikan pelagis kecil. Selain itu, secara ekonomi dapat meningkatkan pendapatan masyarakat khususnya nelayan yang berada di wilayah pesisir (Nelwan dkk, 2015).

Kegiatan penangkapan ikan dengan API bagan cungkil di Desa Lamurukung di lakukan selain untuk kegiatan mata pencaharian nelayan dalam kehidup sehari-harinya juga dilakukan sebagai usaha dalam bidang penangkapan ikan. Analisa kelayakan usaha pada pengoprasian API bagan cungkil sangat diperlukan untuk keberlanjutan usaha penangkapan ikan dan peningkatan kesejahteraan nelayan itu sendiri. Menurut Sulianto 2010, menyatakan bahwa bagaimana kesiapan permodalan yang akan digunakan untuk menjalankan bisnis dan apakah bisnis yang akan dijalankan dapat memberikan tingkat pengembalian yang menguntungkaan. Untuk itu analisa kelayakan usaha perlu untuk dilakukan pada pengoprasiaan API bagan cungkil.

Analisa kelayakan usaha diperlukan, untuk mengetahui apakah usaha yang akan dilakukan atau yang sedang dilakukan layak atau tidak layak untuk dilanjutkan. Beberapa metode dapat digunakan untuk menilai kelayakan invesstasi yaitu : Payback period (PP), net present value (NPV), profitability indeks (PI), internal rate of return (IRR), dan average rate of return (ARR) (Sulianto, 2010). Selanjutnya Umar 2015 menyatakan bahwa ada empat metode yang biasa dipertimbangkan untuk dipakai dalam penilaian aliran kas dari suatu infestasi, yaitu metode payback period, net present value, internal rate of return, dan profitability index. Tujuan dari penelitian ini adalah untuk melakukan analisis kelayakan usaha pengoperasian API bagan perahu.

\section{Bahan dan Metode}

Penelitiaan dilaksanakan di Desa Lamurukung Kecamatan Tellu Siattinge Kabupaten Bone Provinsi Sulawesi Selatan mulai Agustus 2018 sampai dengan Juli 2019. Metode yang digunakan dalam penelitian ini adalah metode deskriptif yang bersifat studi kasus. Metode deskriftif yaitu suatu metode dalam menilai status sekelompok manusia, suatu objek, suatu set kondisi, suatu system pemikiran ataupun suatu kelas peristiwa pada masa sekarang, (Nazir, 2009). Sehingga tujuan dari penelitian deskriptif ini adalah untuk membuat deskripsi, gambaran, atau lukisan secara sistematis, faktual dan akurat mengenai fakta-fakta, sifat-sifat serta hubungan antarfenomena yang diselidiki, dalam hal ini yang menjadi objek penelitian adalah nelayan yang melakukan usaha penangkapan ikan dengan alat penangkap ikan bagan cungkil. Studi kasus dalam penelitian ini dimaksud dalam pengambilan sampel dilakukan pada nelayan yang melakukan usaha penangkapan ikan dengan alat penangkap ikan bagan cungkil yang mempunyai kriteria sebagai berikut : modal merupakan modal sendiri dan tidak ada kredit dari bank atau dengan yang lainnya, penerimaan hanya diperoleh dari penjualan hasil tangkapan, biaya penyusutan di asumsikan 15 tahun untuk umur ekonomis perahu/kapal, 20 tahun untuk umur ekonomis mesin, dan 3 tahun untuk umur ekonomis alat tangkap.

Data yang diperoleh dari kegiatan usaha penangkapan ikan menggunakan alat penangkap ikan bagan cungkil yang dilakukan oleh nelayan selanjutnya dianalisa dengan mengunakan analisa rugi/laba, payback period (PP), net present value (NPV), dan revenue cost ratio ( $\mathrm{R} / \mathrm{C}$ ratio). Analisa rugi/laba bertujuan untuk mengetahui besarnya keuntungan atau kerugian dari usaha yang dikelola. Suatu usaha yang menguntungkan akan memiliki nilai penerimaan lebih besar dari total pengeluaran, dimana rumus untuk menghitung rugi/laba adalah total penjualan di kurangi total biaya. Sedangkan rumus untuk menghitung payback period adalah Investasi kas bersih di bagi aliran kas masuk bersih tahunan. Payback period merupakan metode yang digunakan untuk menghitung lama periode yang diperlukan untuk mengembalikan uang yang telah di investasikan dari aliran kas masuk (proceeds) tahunan yang dihasilkan oleh proyek investasi tersebut (Suliyanto, 2010).

Metode net present value merupakan metode yang dilakukan dengan cara membandingkan nilai sekarang dari aliran kas masuk bersih (proceeds) dengan nilai sekarang dari biaya pengeluaran suatu 
investasi (outlays) (Suliyanto, 2010). Sedangkan revenue cost ratio adalah perbandingan antara total penerimaan dengan total biaya (Soekartiwi, 2006). Jika R/C ratio lebih dari 1 maka usaha yang dijalankan mengalami keuntungan atau layak untuk di kembangkan.

\section{Hasil dan Pembahasan}

\subsection{Analisa Raba Lugi}

Analisa rugi laba ini menggambarkan usaha pengoprasian alat penangkapan ikan bagan perahu mendapat keuntungan atau kerugian dalam satu periode pengoprasian. Unit usaha dikatakan dapat berjalan dengan baik apabila dari segi ekonomis mendapatkan keuntungan yang maksimal dari usahanya.

Analisa rugi laba ini diperoleh dari total penerimaan dikurangi dengan total biaya yang dikeluarkan dalam satu periode perhitungan yaitu satu tahun. Nilai keuntungan yang diperoleh dari usaha pengoprasian alat penangkapan ikan bagan perahu sebesar Rp. 233.464.667/tahun sehingga keuntungan bersih pemilik bagan perahu (pemilik usaha) tersebut sebesar Rp. $233.464 .667 \times 50 \%=$ Rp.116.732.334/tahun dan bila di bagi 12 bulan maka keuntungan yang diperoleh per bulannya sebesar Rp. 9.727.694. Nilai 50\% merupak biaya tenaga kerja, nilai ini merupakan kesepakatan bagi hasil (pihak nelayan/crew kapal 50\% dan pemilik kapal 50\%) dari pendapatan yang diperoleh pada pengoprasian alat penangkapan ikan bagan perahu di desa Lamurukung kecamatan Lamuru kabupaten Bone.

\section{Tabel 1. Biaya Usaha Pengoprasian Alat Penangkapan Ikan Bagan Perahu.}

\begin{tabular}{clc} 
No & \multicolumn{1}{c}{ Aspek Ekonomi } & Jumlah (Rp) \\
\hline 1 & Biaya Penyusutan & 41.833 .333 \\
2 & Biaya Perawatan & 23.880 .000 \\
3 & Biaya Operasional & 178.200 .000 \\
\hline & Total Biaya & $\mathbf{2 4 3 . 9 1 3 . 3 3 3}$ \\
\hline
\end{tabular}

Tabel 2. Pendapatan Usaha Pengoprasian Alat Penangkapan Ikan Bagan Perahu

\begin{tabular}{cllcc} 
No & \multicolumn{1}{c}{ Jenis Ikan } & Harga/Kg & Jumlah Tangkapan & Jumlah (Rp) \\
\hline 1 & Ikan Tongkol & Rp. 4.700 & $25.740 \mathrm{Kg}$ & 120.978 .000 \\
2 & Ikan Teri & Rp. 3.500 & $79.200 \mathrm{Kg}$ & 277.200 .000 \\
3 & Cumi-cumi & Rp. 24.000 & 3300 & 79.200 .000 \\
\hline \multicolumn{7}{c}{ Total } \\
\hline
\end{tabular}

\section{a. $\quad$ Payback Period (PP)}

Payback period merupakan analisis yang digunakan untuk mengetahui jangka waktu pengembalian modal. payback period merupakan metode yang digunakan untuk menghitung lama periode yang diperlukan untuk mengembalikan uang yang telah di investasikan dari aliran kas masuk (proceeds) tahunan yang dihasilkan oleh proyek investasi tersebut (Suliyanto, 2010). Hasil Analisa dengan cara menghitung Investasi kas bersih di bagi aliran kas masuk bersih tahunan menunjukan bahwa nilai payback period pada usaha pengoprasian alat tangkap bagan perahu sebesar 1,56. Nilai ini menunjukan bahwa usaha penangkapan ikan dengan menggunakan bagan perahu dapat mengembalikan modal usaha setelah jangka waktu 1 tahun 5 bulan, ini berarti tingkat pengembalian modal pada usaha tersebut tergolong cepat karna masa pengembalian modal kurang dari 3 tahun. 


\section{b. $\quad$ Net Present Value (NPV)}

Net present value merupakan metode yang dilakukan dengan cara membandingkan nilai sekarang dari aliran kas masuk bersih (proceeds) dengan nilai sekarang dari biaya pengeluaran suatu investasi dengen memperhatikan tingkat suku bunga yang berlaku, dimana tingkat suku bunga yang digunakan pada analisa ini sebesar $6 \%$. Hasil Analisa net present value pada usaha pengoprasian alat penangkapan ikan bagan perahu sebesar 53.722.736,4. Net present value positif maka infestasi diterima, ini artinya bahwa usaha pengoprasian alat penangkapan ikan bagan perahu layak unutk di lanjutkan dan dikembangkan.

\section{c. Revenue Cost Ratio (R/C Ratio)}

Revenue cost ratio merupakan rasio tingkat keuntungan yang dapat diperoleh dengan membagi total penerimaan (revenue) dengan total biaya yang dikeluarkan (cost). Keuntungan diperoleh apabila total penerimaan lebih besar dibanding dengan total biaya yang dikeluarkan. Jika revenue cost ratio $<1$ maka usaha tidak menguntungkan, dan jika revenue cost ratio = 1 maka usaha berada pada titik impas, namun bila revenue cost ratio $>1$ maka usaha tersebut menguntungkan. Nilai revenue cost ratio pada pengoprasian alat penengkapan ikan bagan perahu menunjukan nilai 1,95, ini artinya usaha tersebut menguntungkan dan layak untuk di kembangkan.

\section{Kesimpulan}

Analisis kelayakan usaha pengoprasian alat penangkapan ikan bagan perahu di tempat pelelangan ikan desa Lamurukung kecamatan Lamuru kabupaten Bone menunjukan nilai keuntungan pertahun sebesar Rp. 233.464.667, nilai payback periode 1,56, nilai net present value pada usaha pengoprasian alat penangkapan ikan bagan perahu sebesar $53.722 .736,4$ dan nilai revenue cost ratio 1,95. Sehingga usaha pengoprasian alat penangkapan ikan bagan perahu yang di lakukan di Desa Lamurukung kecamatan Lamuru kabupaten Bone layak untuk di lanjutkan dan di kembangkan.

\section{DAFTAR PUSTAKA}

Areta, dkk 2017. Analisis Kelayakan Usaha Perikanan Tangkap Bagan Perahu (Cungkil) di PPP Lempasing Bandar Lampung. Fakultas Perikanan dan IImu Kelautan. Universitas Diponegoro. Semarang.

Nazir, M. (2009). Metode Penelitian. Penerbit : Ghalia Indonesia. Jakarta

Nelwan, dkk 2015. Produktifitas Penangkapan Ikan Pelagis di Perairan Kabupaten Sinjai Pada Musim

Peralihan Barat-Timur. Program Studi Pemanfaatan Sumberdaya Perikanan. Universitas Hasanuddin. Makassar.

Suherman, A dkk 2005. Penggunaan Lampu Mercury dalam Perikanan Mini Purse Seine di Jepara. Fakultas Perikanan dan Ilmu Kelautan. Universitas Diponegoro. Semarang.

Sulianto, 2010. Studi Kelayakan Bisnis. Penerbit : Andi Yogyakarta. Yogyakarta.

Umar husein, 2015. Studi Kelayakan Bisnis. Penerbit : PT Gramedia Pustaka Utama. Jakarta. 